\title{
PENGARUH MEDIA PEMBELAJARAN LEGO UNTUK MENINGKATKAN KREATIVITAS ANAK USIA DINI
}

\author{
Kartini, Indria Susilawati \\ Program Studi PG-PAUD, STKIP Meawi \\ Program Studi Penjaskesrek, STKIP Melawi \\ Email: Kartini.lombok88@gmail.com,smile_indria@yahoo.com
}

\begin{abstract}
Abstrak
Penelitian ini bertujuan untuk mengetahui: (1) pengaruh kreativitas anak usia dini pada pembelajaran sebelum dan sesudah menggunakan media lego, (2) Pengaruh kreativitas antara kelompok anak yang diajarkan dengan media lego dan media konvensional di TK Global Melawi. Jenis penelitian yang digunakan adalah penelitian kuasi eksperimen dengan desain pretest-postest control group design. Teknik observasi digunakan untuk mengetahui kreativitas anak. Teknik analisis data menggunakan uji t-test. Hasil penelitian ini menunjukkan bahwa: (1) ada pengaruh kreativitas anak usia dini pada pembelajaran sebelum dan sesudah menggunakan media lego (Balok, (2) ada pengaruh yang signifikan mengenai kreativitas anak kelompok eksperimen dengan kelompok kontrol. Prolehan mean kreativitas eksperimen lebih besar dari pada mean kelompok kontrol yaitu 37,00 > 31,17. Hasil uji-t dan posttest kemampuan kreativitas kelompok kontrol dan eksperimen menunjukkan bahwa nilai t-tabel dengan derajat bebas (df) 34 dengan taraf signifikansi $\alpha=0,05$ adalah sebesar 2,032. Nilai t-hitung 3,389 > t-tabel 2,032 dan nilai $p$ value $0.000<$ taraf signifikansi 0,005
\end{abstract}

Kata Kunci. : Pengaruh, Media Lego, Kreativitas

\section{Abstract}

This research aims to know: (1) there are effect of early childhood creativity of learning before and after using lego, (2) the effect of creativity in learning by using lego and conventional of children group at TK Gelobal Melawi. This research used quasi-experiment with pretese-posttest control group design. The data collection techinique used abservation. Analysis data technique was done with T-test result of the research was (1) there are effect of early childhood creativities in learning before and after using lego media, (2) there are significance effect between creativities the experiment and control group. Creativity experiment mean was bigger than control group $37.00>31.17$. the result of $T$-test data from post-test, the creativity ablity of control and experiment group showed that $t$-table with standard deviation (df) 34 with significance $\alpha=0.05$ was 2.032. $t_{\text {-count }}$ score $3.389>t_{\text {-table }} 2.032$ and $p$-value $0.000<$ significance 0.05 .

Keywords: the effect, lego media, creativity 


\section{Dunia Anak: Jurnal Pendidikan Anak Usia Dini, 1 (2), November 2018 Kartini, Indria Susilawati}

\section{PENDAHULUAN}

Pendiidkan anak usia dini memegang peran yang sangat penting dalam perkembangan anak karena merupakan pondasi dasar dalam keperibadian anak. Dimana anak usia dini adalah generasi penerus bangsa dipundak merekalah kita akan menyerahkan peradaban yang telah kita bangun dan akan kita tingalkan. Anak berusia 0-6 tahun memiliki masa perkembangan kecerdasan yang sangat pesat sehingga masa ini disebut golden age ( masa keemasan). Masa ini merupakn masa dasar terutama dalam mengembangkan beragai kegiatan dalam rangka pengebangan potensi, sikap, keterampilan daln kreativitas pada anak usia dini. Undang -undang No 20 tahun 2003 ayat 14 dinyatakan bahwa pendidikan anak usia dini (PAUD) adalah suatu upaya pembinaan yang ditujukan kepada anak sejak lahir sampai dengan usia 6 tahun yang dilakukan melalui pemberian rangsangan pendidikan untuk membantu pertumbuhan dan perkembangan jasmani dan rohani agar anak memiliki kesiapan dalam memasuki tahap pendidikan selanjutnya. Pendidikan anak usia dini merupakan tempat belajar sekaligus bermain bagi anak. Anak di ajarkan mengenal aturan, disiplin tanggung jawab dan kemandirian dengan cara bermain. Anak juga diajarkan bagaimana mereka harus menyenyesuaikan diri dengan lingkungannya, berempati, dengan teman-temannya tentu juga berlatih berkerja sama dengan anak yang lain. Suyanto (2006) menyatakan bahwa melalui kegiatan bermain yang mengandung edukasi, daya pikir anak terangsang untuk perkembangan emosi, sosial dan fisik. Setiap anak memiliki kemampuan dan keterampilan bermain yang berbeda tergantung dari perkembangan anak. Dari permainan biasanya akan menimbulkan fantasifantasi besar oleh anak, dan tentu akan semakin menambahkan rasa ketertarikan anak pada mainan tersebut Montolalu (2008) mengatakan bahwa bermain bagi anak-anak mempunyai pengaruh yang sangat penting karena melalui bermain anak dapat menyalurkan segala kegiatan, kepuasan, kreativitas dan imajinasi. Dengan demikian, anak dapat menjadi kreativ melalui kegiatan bermain Nugraha (2008) menyatakan perkembangan kreativitas pada anak prasekolah atau usia dini merupakan tujuan terpenting yang mesti diakomodasi kurikulum, karena anak yang kreatif akan mampu mengaplikasikan kemampuan kognitif, efektif, dan psikomotoriknya secara lebih luas, melalui berbagai gagasan untuk kemampuan atau keterampilan baru produk beda/ sesuatu atau bentuk pertanyaan-pertanyaan. Susan (2012) creativity is theprocess of generating ideas that are novel and bringing into existence product that is appropriate and of high quality. Kreativitas merupakan proses memicu ide-ide dan merealisasikannya dala bentuk produk nyata yang berkesesuaian dan memiliki kualitas yang tinggi.

Kreativitas merupakan proses memicu ideide dan merealisasikannya dalam bentuk produk nyata yang berkesesuaian dan memiliki kualitas yang tinggi masa anak merupakan masa belajar yang potensial. Kurikulum untuk anak usia dini atau TK harus bener-bener memenuhi kebutuhan anka dan sesuai dengan tahap perkembangan serta 


\section{Dunia Anak: Jurnal Pendidikan Anak Usia Dini, 1 (2), November 2018}

Kartini, Indria Susilawati

dirancang untuk membuat anak mengembagkan potensinya secara utuh. Kreativitas anak dimungkinkan akan tumbuh dan berkembang dengan baik apabila lingkungan keluarga, rumah maupun sekolah turut menunjang mereka dalam mengekspresikan kreativitasnya. Lingkungan memiliki pengaruh yang besar dalam perkembangan kreativitas anak. Kreativitas seorang anak tidak akan berkembang jika lingkungan tidak mendukung dalam era globalisasi ini, orag tua harus banyak melihat dan mengetahui bagaimana perkembangan anak, seperti perkembangan kreativitas anak. Semua orang tua menginginkan anaknya menjadi anak yang berbakat dan kreatif. Akan tetapi mereka tidak tahu bagaimana merangsang kreativitas anak itu sendiri. Bahkan orang tua tidak mengetahui dan tidak mau tahu seperti apa ciri-ciri anak kreatif. Berdasarkan observasi awal di TK Gelobal sebelum penelitian, kegiatan pembelajarannya cendrung berupa pembelajaran yang (teacher centered) dimana anak dituntut untuk menguasai kemampuan membaca, menulis dan berhitung (Calistung). Guru cendrung berperan dominan dalam pembelajaran, guru mengarahkan anak untuk belajar sesuai dengan keinginannya dan lebih menyukai hasil anak sesuai dengan apa yang diperintahkannya sehingga anak tidak mempunyai kesempatan untuk memilih jenis kegiatan yang sesuai dengan minat kreativitas anak tidak berkembang. Karena guru maupun orang tua masih beranggapan bahwa kreativitas anak sebagai hal yang biasa saja. Mereka lebih menekankan kemampuan anak dari segi akademik.
Dalam mengembangkan kreativitas anak perlu digunakan cara-cara tertentu dalam diri anak. Salah satunya yaitu dengan menerapkan permainan. Permainan adalah salah satu media pembelajaran yang dapat mengembangkan kreativitas, meningkatkan motivasi dan dapat mengurangi rasa bosan dan jenuh pada belajar.

Media pembelajaran memiliki perang yang penting dalam mengembangkan kreativitas anak. Namun, sekarang ini media pembelajaran di taman kanak-kanak yang dapat meningkatkan kreativitas anak masih kurang. Hal ini terlihat ketika guru memberikan sebuah kertas kosong dimana seluruh anak diminta untuk menggambar, sebagian besar anak tampak bingung, apa yang akan digambarkan di kertas tersebut. Selain itu, media pembelajaran yang disediakan tidak menarik atau kurang efektif dimana media pembelajaran hanya terpaku pada lembar kerja siswa (LKS) atau bersifat tekstual, sehingga proses pembelajaran telihat monoton dan membuat anak cepat bosan untuk mengikuti proses pembelajran. Oleh karena itu, perlu disediakan media yang dapat memfasilitasi perkembangan kreativitas anak yang disesuaikan dengan kebutuhan dan perkembangan anak. Permainan yang dapat mengembangkan kreativitas anak adalah media permainan Lego (balok).

Lego adalah sejenis alat permainan balok yang terbuat dari plastik kecil yang terkenal di dunia khususnya di kalangan anak-anak atau remaja tidak memandang laki-laki ataupun perempuan. Balok-balok ini serta kepingan lain bisa disusun menjadi model apa saja. Mobil, kereta api, bangunan, kota, patung, istana, kapal terbang, 


\section{Dunia Anak: Jurnal Pendidikan Anak Usia Dini, 1 (2), November 2018 Kartini, Indria Susilawati}

rumah, semuanya bisa dibuat. Bermain bongkar pasang balok warna alias lego memang mengasyikkan. Permainan ini tidak mengenal batas usia. Mulai dari anak-anak sampai orang dewasa senang bermain lego. Permainan ini menyenangkan dan bisa meningkatkan kreativitas karena bermain membutuhkan imajinasi dandaya pikir pemainnya. Model tertentu yang diinginkan pemain seperti gedung, hewan, kapal, maupun bentuk lainnya menjadi buah karya yang bisa memacudaya pikir otak. Permainan lego adalah salah satu permainan yang palingpopular di dunia anak-anak, lego adalah sebuah permainan yang tidak hanyamenikmati tetapi juga untuk mengembangkan imajinasi dan kemampuan berpikir kreatif. Permainan lego disini tergolong ke dalam permainan konstruktif dan permainan konstruktif sendiri tergolong ke dalam permainan produktif Sudono (2000). Media lego hampir sama dengan media balok Mulyadi (2004) menjelaskan bermain balok/lego adalh jenis kegiatan yang sifatnya konstruktif, dimana anak mampu membangun sesuatu dengan menggunakan balok/lego yang sudah disediakan. Hal ini senada dengan pendapat Segal (2012) bahwa That builiding with block,toddlers enjoy creating and experimenting with blocks. They are learning how to carry blocks, line up blocks, stack blocks, balance bigger blocks on smaller blocks, and nest blocks in unique. Provide blocks of different sizes, shapes, and textures as well as cardboard blocks, nesting blocks, plastic blocks, and small unit blocks. Also provide block that snapor stick together easily and can be used to create a variety of buildings, vechicles, funiture, or designs.

Segal menyatakan kegiatan menyusun balok, anak dapat menikmati meciptakan dan mengadakan percobaan dengan media balok/lego. Mereka belajar tentang bagaimana membariskan balok/lego, menumpukkan balok/lego, menyeimbangkan balok/lego yang lebih kecil ke atas balok yang lebih besar dan menyusun balok dengan cara yang unik. Penyediaan balok/ lego dengan berbagai ukuran dan bentu, tekstur yang berbeda maupun pengumpulan kardus balok, balok plastik (lego) dan unit balok yang kecil-kecil serta penyediaan balok yang berbetuk kotak atau batangan dengan cara bersama-sama memudahkan dan bisa digunakan untuk menciptakan susunan bangunan yang berpariasi, wahana prabotan atau rancangan.

Pengembangan kreativitas anak sangat perlu dikembangkan kepada anak sejak dini agar anak matang ketika memasuki usia sekolah. Anak siap menghadapi permasalahan yang muncul. Setiap media permainan dapat difungsikan secara multiguna dan memiliki kekususan untuk mengembangkan aspek perkembangan pada anak, selain itu balok atau lego dapat dimainkan dengan berbagai cara dan bentuk untuk melatih tidak hanya aspek motorik halus tetapi juga dapat mengenal konsep warna, ukuran dan bentuk pada anak sehingga muncul kreativitas anak.

Kreativitas adalah kemampuan menemukan banyak kemungkinanjawaban terhadap suatu masalah. Kreativitas dapat dilihat dari segi kognitif (berpikir kreatif), afektif (sikap kreatif), dan 
Kartini, Indria Susilawati

psikomotor (ketrampilan, misalnya mampu menggunakan kuas atau membentuk dan lainnya), kreativitas juga menciptakan atau menghasilkan sesuatu yang baru dengankegiatan kreatif. Bermain merupakan pengalaman belajar yang berharga bagi anak-anak. Sepanjang masa kanak- kanak, bermain sangat mempengaruhipenyesuaian pribadi dan sosial anak. Pengaruh ini mungkin sedikit berbeda dari satu tingkat perkembangan ketingkat perkembangan lainnya. Melalui bermain seorang anak dapat memperoleh kesempatan belajar diantaranya pemecahan masalah dan kreativitas. Melalui eksperimentasi dalam bermain, anak-anak menemukan bahwa merancang sesuatu yang baru dan berbeda dapat menimbulkan kepuasan dan mereka dapat mengalihkan minat kreatifnya ke situasi di luar dunia bermain. Anak yang sedang tumbuh memerlukan sarana dan fasilitas yang cukup untuk bisa mengembangkan imajinasi dan kreativitasnya. Bentuk-bentuk permainan yang memberi banyak peluang kepada pemainnya untuk menjelmakan berbagai karya dari tingkat yang paling sederhana sampai paling lengkap merupakan stimulan yang sangat berharga dalam upaya menumbuhkan kreativitas anak. Anak harus merasa aman dan bebas secara psikologis, diterima apaadanya, diterima keunikannya dan tidak terlalu di evaluasi. Kondisi inilah yang penting bagi tumbuhnya kreativitas. Dalam hal ini permainan lego turut menyumbang bagi swadaya dan sosialisasi. Karena anak memperoleh kegembiraan dari membuat sesuatu pada saat sendirian, mereka belajar menghibur diri apabila tidak ada teman bermainnya dengan bekerja sama dan menghargai prestasinya. Permainan lego juga merangsang kreativitas. Melalui kegiatan permainan lego, anak menggunakan berbagai benda yang ada untuk menciptakan suatu hasil karya tertentu. Anakanak membuat balok -balok, pasir, lumpur, tanah liat, manik-manik, cat, pasta, glinting, dan krayon. Sebagian konstruksi yang dibuat merupakan tiruan dari apa yang dilihatnya dalam kehidupan seharihari atau dari layar bioskop atau televisi. Dengan membuat beraneka macam bentuk dan hasil karya tertentu, anak tidak hanya dapat mengekspresikan perasaannya saja, namun juga membebaskan dirinya dari berbagai tekanan yang mengganggunya serta dapat mengekspresikan secara nyata apa yang telah dipahaminya. Berbagai manfaat dapat diperoleh dari kegiatan permainan lego, antara lain: mengembangkan kemampuan anak untuk berdaya cipta (kreatif), melatih ketrampilan motorik halus, melatih konsentrasi, ketekunan, dan daya tahan. Apabila anak dapat melakukan permainan tersebut dengan baik, maka dapat menimbulkan rasa puas, penghargaan sosial (pujian dari orang lain) yang akan meningkatkan keinginan anak untuk bekerja lebih baik lagi. Semua anak mempunyai potensi untuk kreatif, walaupun tingkat kreativitasnya bebeda-beda. Anak yang kreatif menghabiskan sebagian besar waktu bermain untuk menciptakan sesuatu yang orisinal dari mainan-mainandan alat-alat bermain, sedangkan anak yang tidak kreatif mengikuti pola yang sudah dibuat oleh orang lain. Para ahli menekankan fungsi 'kesenangan' (pleasure) yang dihasilkan kegiatan bermain lego dan juga merupakan stimulasi untuk bermain. Ketika 


\section{Dunia Anak: Jurnal Pendidikan Anak Usia Dini, 1 (2), November 2018}

Kartini, Indria Susilawati

kemampuan fantasi anak mulai berkembang, fungsi 'kesenangan' ini juga semakin meluas sehingga anak merasakan adanya kenikmatan dalam memproyeksikan serta menciptakan sesuatu yang baru dari apa yang ada dilingkungan sekitarnya. Dengan demikian bermain lego sangat erat kaitannya dengan kreativitas bahkan merupakan awal tumbuhnya kreativitas. Dengan bermain gembira melalui suasana aman dan bebas, anak tampil dengan gagasan-gagasannya yang unik dan lain dari pada yang lain, ia berani bertanya, berani mencoba, tidak takut salah dan berani mengekspresikan pendapat-pendapatnya. Semua ini merupakan awal dari tumbuhnya kreativitas.

Berdasrkan latar belakang tersebut maka peneliti mengambil judul penelitian “ pengaruh media pembelajaran lego untuk meningkatkan kreativitas anak di TK Gelobal.” Penelitian ini bertujuan untuk mengetahui pengaruh kreativitas anak usia dini pada pembeajaran sebelum dan sesudah menggunakan media lego pada kelompok B TK Global di Melawi, pengaruh yang signifikan keativitas anak usia dini dengan menggunakan media pembelajaran lego.

Berdasarkan tujuan penelitian yang hendak dicapai, maka penelitian ini diharapkan dapat memiliki manfaat dalam pendidikan baik secara langsung maupun tidak langsung adapun manfaat secara teoritis hasil penelitian ini diharapkan dapat membrikan sumbangn pemikiran bagi akdemik, dapat memberikan informasi dan kajian tentang belajar dengan media permainan lego/balok dalam meningkatkan kreativitas anak usia dini di taman kanak-kanak, dan memberikan sumbangan ilmu pengetahuan yang bermanfaat terutama dalam pengembangan kreativitas anak usia dini yang diperoleh melalui kegiatan bermain degan belajar yang menyenangkan.

Kajian penelitian yang relevan dilakukan oleh Zahra Universitas Alkhairaat (2011) tentang penerapan belajar melalui bermain dalam meningkatkan kreativitas dan motorik halus anak usia dini pada TK Alkhairaat 1 yang berpusat di kota palu menunjukkan bahwa penerapan pembeajaran melalui bermain balok unit secara signifikan bepengaruh terhadap peningkatan kreativitas dan motorik halus anak sedangkan pada pendekatan konvensional tidak berpengaruh terhadap peningkatan krativitas anak usia dini pada teka alkhairaat. Belajar melalui balok dapat meningkatkan kreativitas dan motorik halus anak usia dini.

\section{METODE PELAKSANAAN}

Penelitian ini menggunakan jenis penelitian quasi eksperimental atau eksperimen semu, karena penelitian ini dilakukan dengan maksud untuk melihat pengaruh dari suatu perlakuan. Tuckman (1972) menyatakan bahwa penelitian kuasi eksperimen seperti halnya penelitian murni namun subjek penelitian tidak dipilih secara acak. Kirk (1995) menyatakan bahwa penelitian kuasi eksperimen didasarkan atas alasan pratis dan etis (etika). Penelitian ini menggunakan pendekatan kuantitatif karena dalam penelitian ini untuk menguji hipotesis yang telah ditetapkan menggunakan analisis statistik dalam megolah 


\section{Dunia Anak: Jurnal Pendidikan Anak Usia Dini, 1 (2), November 2018 Kartini, Indria Susilawati}

data Sugiyono (2010). Penelitian ini menggunakan jenis desain pretes-postes control group Desig. Dalam desain ini kelompok eksperimen maupun kelompok kontrol tidak dipilih secara random, sebelum diberikan perlakukan, kelompok berikan pretes dengan masuk untuk mengetahui keadaan awal apakah ada pengaruh antara kelompok kontrol. Hasil pretes yang baik bila nilai kelompok eksperimen tidak berbeda secara signifikan. Desain ini dapat digambarkan sebagai berikut:

Tabel 1. Pretes-postes control group design

\begin{tabular}{|c|c|c|c|}
\hline Group & Pretes & Treatmen & Postes \\
\hline $\mathrm{A}$ & $0_{1}$ & $\mathrm{X}$ & $0_{2}$ \\
\hline $\mathrm{B}$ & $0_{3}$ & & $0_{4}$ \\
\hline
\end{tabular}

Sugiyono (2012)

Keterangan:

$$
\begin{aligned}
\mathrm{A}= & \text { Eksperimen group } \\
\mathrm{B}= & \text { Kontrol group } \\
0_{1}= & \text { Pretes sebelum diperikan perlakuan } \\
& \text { pada kelompok eksperimen } \\
0_{2}= & \text { Postes setelah diperi perlakuan pada } \\
& \text { kelompok eksperimen } \\
\mathrm{X}_{1}= & \text { Perlakuan media pembelajaran lego } \\
0_{3}= & \text { Pretes pada kelompok kontrol } \\
0_{4}= & \text { Postes pada kontrol }
\end{aligned}
$$

\section{Waktu dan Tempat}

Penelitian ini dilakukan pada bulan februari sampai April 2017 bertempat di TK Gelombal Kabupaten Melawi pada kelompok B.

\section{Populasi dan Sampel}

Populasi dalam penelitian ini adalah seluruh peserta didik TK Gelobal yang ada di kelompok B yang tersebar dalam 3 kelas dengan jumlah anak secara keseluruhan 53. Dalam penelitian ini dipilih kelompok B karena anak-anak yang pada kelompok ini berusia $4-5$ tahun yang sedang berkembang kreativitasnya, sehingga penelitian ini diharapkan dapat bermanfaat bagi perkembangan peserta didik selanjutnya.

Pengambilan sampel dalam penelitian ini dilakukan dengan menggunakan Teknik claster sampling. Penentuan kelompok eksperimen dan kontrol dilakukan secara acak dengan teknik undian maka diperoleh kelompok B1 sebagai kelompok eksperimen dan kelompok B2 sebagai kelompok kontrol.

\section{Prosedur Penelitian \\ Tahap Persiapan}

Memilih dua kelas dari subjek penelitian yang ada untuk dijadikan tempat penelitian. Pemilahan tersebut dilakukan secara acak. Subjek yang dipilih yaitu kelas B1 sebagai kelompok eksperimen dan kelas B2 sebagai kelompok kontrol. Kemudian menyiapkan rancangan pelaksanaan pembelajaran mingguan (RPPM) dan rancangan pelaksanaan pembelajaran harian (RPPH) kedua kelompok yaitu kelompok yang diajarkan dengan media pembelajaran lego dan konvensional. Memberikan pengarahan kepada guru tentang pembelajaran dengan menggunakan media lego untuk meningkatkan kreativitas anak usia dini. Melakukan kesepakatan bahwa pembelajaran dilakukan oleh guru, peneliti hanya sebagai observasi dan patner guru. Selain itu, kegiatan pembelajaran dilakukans sesuai dengan jadwal yang telah direncanakan dan memvalidasi instrumen penelitian dari segi empiris untuk 


\section{Dunia Anak: Jurnal Pendidikan Anak Usia Dini, 1 (2), November 2018 Kartini, Indria Susilawati}

memperoleh instrumen penelitian yang valid dan reliabel.

\section{Tahap pelaksanaan}

Pelasanaan dalam eksperimen ini, terlebih dahulu dilakukan pretes untuk kelompok perlakuan dan kelompok kontrol. Selanjtnya untuk kelompok eksperimen diberikan perlakuan menggunakan media pembelajaran lego, sedangkan pada kelompok kontrol tidak berikan media pembelajaran lego tetapi menggunakan media konvesional. Setelah perlakuan media pembelajaran lego diberikan, peneliti kembali melakukan postes kepada subjek penelitian.

\section{Tahap Kegiatan Akhir}

Tahap kegiatan akhir yaitu melakukan analisis data hasil pretes, postes, pedoman lembar observasi dan penulisan laporan.

\section{Teknik Pengumpulan Data}

Data dalam penelitian bersumber dari anak didik dalam pembelajaran yang berupa perlakuan belajar yang dihasilkan anak. Data yang diambil disini adalah data tentang kreativitas anak usia dini. Pengambilan data pada penelitian ini dilakukan dengan observasi dan dokumentasi. Pengumpulan data melalui observasi yaitu bentuk pengamatan yang dilakukan secara langsung ke objek yang berjumlah 36 responden penelitian, yang terdiri dari 18 objek kelompok lego dan 18 responden kelompok konvensional. Pretes dilakukan dengan mengamati kreativitas anak pretes dimaksudkan untuk mengetahui anak sebelum perlakuan media lego. Dalam pelaksanaan pretes, penelitian dibantu oleh dua observer yaitu guru kelas taman kanak-kanak global. Observasi yang dilakukan meliputi observasi tentang proses peningkatan kreativitas anak setelah menggunakan media pembelajaran lego. Dalam melakukan observasi ini, peneliti berpedoman pada lembar observasi. Dokumentasi digunakan untuk memperoleh data sekolah dan nama siswa kelompok B TK Global. Dokumentasi juga berupa photo proses kegiatan terhadap perlakuan penelitian, yaitu kegiatan proses pembelajaran melalui media lego.

\section{Teknik Analisis Data}

Analisis data dalam penelitian ini menggunakan teknik analisis data uji-t. Penggunaan uji-t dimaksudkan untuk menguji pengaruh mengenai kreativitas anak yang diajarkan mengunakan media pembelajaran lego dengan kelompok kontrol melalui media pembelajaran konvensional. Penghitungan seluruh analisis data dilakukan dengan menggunakan aplikasi SPSS 16.0.

\section{HASIL DAN PEBAHASAN}

Bedasarkan uji hipotesis yang pertama penelitian ini adalah " ada pengaruh kreativitas anak usia dini pada pembelajaran sebelum dan sesudah menggunakn media lego." Berdasarkan hasil pretes dan postes pada pembelajaran lego diketahu perbedaan hasilnya yaitu 37,00 > 29,11 dengan nilai t-hitung sebesar 7, 119 dan nilai $p$ value (sig) sebesar 0,000 nilai $\mathrm{t}-$ tabel dengan derajat bebas (df) 34 taraf signifikasi $\alpha=0,05$ adalah sebesar 2,032. Nilai $\mathrm{t}_{\text {-hitung }} 7,119>\mathrm{t}_{\text {-tabel }}$ 2,032 dan nilai $p$-value $0,000<$ taraf nyata 0,05 . Hal ini menandakan bahwa ada erbedaan yang signifikasi. Oleh karena itu hipotesi $\mathrm{H}_{0}$ di tolak dan 


\section{Dunia Anak: Jurnal Pendidikan Anak Usia Dini, 1 (2), November 2018}

Kartini, Indria Susilawati

$\mathrm{H}_{1}$ diterima sehingga $\mathrm{H}_{1}: \mu^{1} \neq \mu^{2}$ yang berarti ada pengaruh yang signifikan mengenai kreativitas anak antara kelompok anak ynag di ajarkan sebelum dan sesudah menggunakan media pembelajaran lego.

Hasil analisis data penelitian tersebut membuktikan adanya perbedaan yang signifikan mengenai kreativitas anak sebelum dan sesudah menggunakan media lego. Penggunaan media lego terbukti lebih mampu untuk meningkatkan kreativitas anak usia $4-5$ tahun. Hal ini terlihat bahwa ketika mengerjakan kegiatan keterampilan yang diberikan masih banyak terlihat anak yang hanya mencontek kegiatan teman-temannya dan anak tidak berani menambahkan bentuk lain dari contoh yang sudah ada, anak didik banyak yang mulai bosan dengan kegiatan tersebut, sehingga banyak anak yang lebih memilih ngobrol dengan temannya ketika mengerjakan keterampilan menjiplak menggambar dan menggunting disini terlihat kurangnya kreativitas anak yang muncul dikarenakan proses pembelajaran yang menoton. Namun setelah diberikan media pembelajaran lego kreativitas anak mulai meningkat, hal ini disebabkan, ketika proses pembelajaran berlangsung anak-anak sangat antusias dan kelihatan anak -anak senang ketika menggunakan media lego sebagai alat pembelajaran, hal ini terlihat pada kegiatan mereka disaat menyusun, dan membentuk sesuai dengan yang diinginkannya. Penggunaan media lego merupakan salah satu alat permainan yang dapat mendorong imajinasi anak karena melalui media lego ini aan membuat anak suka berkerasi sehingga dapat mengembangkan kreativitasnya. Hal ini sesuai dengan pendapat Ismail (2006) media lego adalah jenis mainan yang dapat digunakan untuk membuat bangunan, mobil, binatang, monster, dan sebagainya. Setiap model membutuhkan kemampuan untuk menemukan balok-balokan yang tepat, baik ukuran maupun bentuknya serta cara mengerjakannya yang terbaik di dalam memasang-masangkannya. Setelah anak semaki tumbuh kepercayaan dirinya, ia mulai dapat memikirkan tentang penggunaan warna dan kesesuaiannya untuk menciptakan model-model ciptaannya sendiri.

Permainan melalui medai lego ini adalah sebuah permainan yang dirancang khusu untuk meningkatkan kreativitas dan mengembangkan kemampuan motorik halus anak yang berusia 4-5 tahun. Berdasarkan hasil penelitian ini maka dapat dibuktikan bahwa media lego memiliki pengaruh yang signifikan terhadap kereativitas anak usia dini.

Berdasarkan uraian pembahasan di atas, perlakuan diberikan kepada kelompok eksperimen dengan media lego dan kelompok kontrol dengan pembelajaran konvensional. Pada proses pembelajaran yang diterapkan berpusat pada peserta didik dan bukan pada peendidik namun pada pendidik hanya memberikan penerapanpenerapan cara mengembangkan kreativitas anak melalui media-media permainan khususnya pada media lego. Oleh karena itu, diperlukan berbagaimacam untuk mewujudkan proses yang memberikan kesempatan kepada peserta didik untuk mengembangkan potensi kreativitasnya. 


\section{Dunia Anak: Jurnal Pendidikan Anak Usia Dini, 1 (2), November 2018}

Kartini, Indria Susilawati

Maka dari itu, salah satu usaha untuk mencapai tujuan tersebut adalah dengan melakukan dan menerapkan suatu media pembelajaran khususnya melalui media lego. Melalui penggunaan media lego merupakan salah satu cara memberikan kesempatan berkembangnya kreativitas, melatih keterampilan motorik halusnya, karena melalui permainan lego anak dapat menciptakan berbagai macam benda seperti membuat rumah, kereta api, kolam ikan, trowongan dan masih banyak lagi yang lainnya. Dimayanti (2008) menyatakan bahwa salah satu manfaat dari pembelajaran menggunakan media lego yaitu anak dapat meningkatkan motorik kasar, motorik halus serta kreativitas. Selain itu, anak juga dapat mengenal konsep matematika yaitu dapat mengenal konsep berat, ringan, panjang, pendek, besar, kecil, tinggi, rendah, dan mampu mengelompokkan benda berdasarkan bentuk dan warnanya.

Media pembelajaran memiliki peran yang penting dalam pengembangan kreativitas anak. Kegiatan pembelajaran itu harus harus dibuat menyenangkan, menarik perhatian anak dan membuat anak nyaman agar proses pembelajaran dapat berlangsung lebih efektif. Pernyataan ini diperkuat dengan hasil penelitian Lloyd \& Howe (2003) bahwa anak-anak tidak menggunakan waktu bermain secara individu mereka untuk kegiatan yang memiliki tujuan yang pasti. Hal ini sejalan dengan pendapat Miarso (2007) bahwa media pembelajaran merupakan alat yang digunakan untuk menyalurkan pesan serta dapat merangsang pikiran, perasaan, perhatian sehingga kemauan anak dalam belajar dapat terdorong untuk menciptakan proses pembelajaran yang bertujuan dan terkendali. Karena melalui media merupakan salah satu metode yang dapat memberikan kesenangan pada anak dan membantu anak kreatif. Untuk mewujudkan bakat kreativitas seorang anak, diperlukan dorongan melalui media pembelajaran yaitu media pembelajaran lego yang merupakan salah satu media yang disenangi oleh anak-anak serta dapat meningkatkan kreativitas yang dimiliki oleh anak. Penggunaan media pembelajaran lego terbukti mampu untuk meningkatkan kreativitas anak usia 4-5 tahun. Penggunaan media lego merupakan salah satu alat permainan yang dapat mendorong imajinasi anak. Karena melalui media lego ini akan membuat anak suka berkreasi sehingga dapat mengembangkan kreativitasnya.

Berdasarkan penelitian Howard-Jones (2002) yang dilakukan pada 52 anak usia 6 tahun. Sebagian anak diberikan lego ke mudian diberikan untuk bermain selama 25 menit. Hasilnya menujukkan bahwa anak yang bermain lego memiliki kreativitas yang lebih tinggi jika dibandingkan anak yang tidak diberikan lego.

Berdasarkan hasil penelitian maka dapat dibuktikan bahwa antara media pembelajaran lego dengan media pembelajaran konvensional memiliki pengaruh yang signifikan untuk meningkatkan kreativitas anak usia dini. Oleh karena itu penggunaan media lego dapat dijadikan pilihan utama dalam meningkatkan kreativitas anak usia dini. 


\section{Dunia Anak: Jurnal Pendidikan Anak Usia Dini, 1 (2), November 2018 Kartini, Indria Susilawati}

\section{SIMPULAN}

Berdasarkan pembahasan pada bab-bab sebelumnya, maka dapat ditarik kesimpulan bahwa ada pengaruh yang signifikan mengenai kreativitas anak usia dini antara kelompok anak yang diajarkan menggunakan media pembelajaran lego dengan kelompok kontrol yang menggunakan media pembelajaran konvensional. Hal ini terbukti pada perolehan mean kreativitas kelompok eksperimen lebih besar dari pada kelompok kontrol yaitu 37,00 > 31,17 dengan nilai t-hitung $3,389>\mathrm{t}_{\text {-tabel }} 2,032$ serta $p$-value $0,002<$ taraf nyata 0,05

\section{DAFTAR RUJUKAN}

Depdiknas. (2003) Standar Kompetensi Pendidikan Anak usia Dini. Jakarta: departemen Pendidikan Nasional.

Howard-Jones, P.A., Taylor, J., \& Sutton, L. (2002). The effect of play on the creativity of young children during subsequent activity. Journal Early Child Developmen and care

Ismail, A. (2006). Education game menjadi cerdas dan ceria dengan permainan edukatif. Yogyakarta: Pilar Media

Krik, R.E. (1993) Experimental desingn: procedure for the behavoiral sciences. California. Broks Cole Publishing Company.

Lloyd, B. \& Howe, N (2003). Solitary play and convergent and divergent thinking skill in. Preschool Children. Journal Early Childhood Research Quartely.

Miarso, Yusufhadi. (2007). Menyamai benih teknologi pendidikan. Jakarta: kencana

Montolalu, dkk. (2008). Bermain dan permainan anak. Jakarta: universitas terbuka
Nuggraha, A, dkk. (2008). Materi pokok kurikulum dan bahan belajar TK. Jakarta: universitas Terbuka

Sugiyono, (2010). Metode penelitian pendidikan pendekatan kuantitatif, kualitatif dan R\&D. bandung: Alfabeta

(2012).Metode penelitian pendidikan pendekatan kuantitatif, kualitatif dan R\&D. bandung: Alfabeta

Susan, (2012). Understanding creativity early childhood. London: Age

Suaynto, S. (2005). Dasar-Dasar Pendidikan anak usia dini. Yogyakarta: Hikayat

Swartz, M.I, (2005). What's standard. Young children. New youk: Mc Graw Hill

Tuckman, B.W., (1972). Conducting education researc. New Youk: Harcourt Brace Jovanovich, inc

Zahrah (2011). Penerapan belajar melalui bermain dalam meningkatkan kreativitas dan motorik halus anak usia dini. Skripsi, tidak dipublikasikan . Universitas Alkhairat. 